\title{
Navigation and Fishing on the Ganges.
}

THE first of Mr. Hornell's two memoirs ${ }^{\top}$ deals with the various navigation appliances employed on the Ganges. These are studied under two main groups, representing respectively the primitive and the advanced types. The former comprises rafts, dug-outs, skins, and other rudimentary forms adapted to simple requirements. Inflated buffalo-skins, used either singly as floats to support a swimmer, or by associating together two or more to give buoyancy to a platform-raft, are still in use locally on the Ganges, just as they are on the Tigris, as direct survivals from the ancient Babylonian and Assyrian days. It is curious that the skin-covered coracle, which also was used in ancient Mesopotamia, is not represented in this part of India; its absence being the more noteworthy since it is prevalent both in southern India and in the Trans-Himalayan regions (e.g. Tibet). On the Ganges its place seems to be taken by the Tigari of Eastern Bengal, a circular, round-bottomed pottery bowl, in which one man can sit and propel himself with a short paddle.

Of the dug-out canoes, the most peculiar are those made from the stem of the Palmyra-palm (Borassus). The base of the stem is much swollen, and the canoe, retaining the natural shape, is thickened and rounded at one end and narrow at the truncated other end, which is usually plugged with clay. These canoes are often used in pairs, lashed together to give stability. The type occurs also on the Colair Lake in Madras Presidency.

The difficulty and cost of obtaining large treetrunks for making dug-outs is encouraging the increasing adoption of plank-built boats, of which $\mathrm{Mr}$. Hornell describes several varieties, from the small, one-man dinghi to large barges and house-boats. The author points out that the Gangetic built-boat types do not link up with types seen farther east

" "The Boats of the Ganges " and "The Fishing Methods of the Ganges," by J. Hornell. Memoirs of the Asiatic Society of Bengal, vol. 8, No. 3, 1924, pp. I71-238. Rupees 2.13.
(Burma, Siam, and China), but with western forms; and he urges the probability of a close link with the Mediterranean vessel-types. He suggests that these boat-designs may have been introduced by Dravidians who entered India through Balnchistan. He refers to the use of the oculus on some of the Gangetic vessels, and offers this as an important link with Egypt and the Mediterranean. In Fig. I4 the oculus is described as being situate upon the "sternhead " and this evident misprint for "stem-head" occurs more than once in the text.

This treatise is a useful adjunct to one published by Mr. Hornell in the same "Memoirs" in 1920 (7, pp. I39-256).

The second memoir is devoted to the fishing methods of the Ganges, dealt with under three environmental conditions-estuarine, riverine, and lacustrine. The first and last mainly involve shallow, still-water fishing; the second-by far the most important-is chiefly characterised by swift, deep waters. The various appliances are described in detail. Spearing fish with simple, many-pointed, or harpoon-headed spears, and also shooting them with bow and arrow, are still practised extensively. The art of trapping fish has been highly developed, great ingenuity being exhibited in designing and constructing the numerous varieties of traps. The same may be said of the netting-gear, which has been even more specialised into a great diversity of types adapted to different quarries and varied waters. Line-fishing, with or without a rod, is also popular, and much ingenuity is evinced in the practice of ground-baiting. The author has added an important item to the literature of fishing, which will prove of value when a long-wanted monograph is produced dealing with the primitive fishing methods of the world, their distribution and ethnological significance.

In both these memoirs the illustrations are very good and clear.
HENRY BALFOUR.

\section{Synthetic Methyl Alcohol.}

$\mathrm{T}^{\mathrm{H}}$

E first attempt to synthetise methyl alcohol by the catalytic reduction of carbon monoxide was apparently made by Sabatier and Senderens. These experiments were unsuccessful, but French research workers have persevered on the problem and the manufacture of methyl alcohol is now an accomplished fact. An accidental synthesis was carried out by the Badische Anilin- und Soda-Fabrik in I9I3, during experiments carried out to investigate the possibilities of manufacturing liquid hydrocarbons by the catalytic reduction of carbon monoxide at high temperatures and pressures. No attempt was made, however, to pursue the investigation. In I92 I Calvert claimed to have obtained an 80 per cent yield of methyl alcohol by the action of hydrogen on water gas, and in the same year Patart, Inspecteur Général des Poudres, published his first patent. A small plant was erected at Asnières and Patart's method was successfully applied.

In Patart's process the gaseous mixture, containing two volumes of hydrogen to one of carbon monoxide, is compressed to $250-500$ atmospheres and, after filtration, is passed over the electrically heated catalyst $\left(400^{\circ}\right)$. The gases are then cooled and the non-condensed portion re-circulated through the apparatus. A suitable catalyst is zinc oxide; it yields a greenish liquid containing a greenish precipitate of metallic copper from the apparatus. The liquid readily yields practically pure methyl alcoho] on distillation with phosphoric acid, followed by a redistillation of the first portion of the distillate. The final product has a somewhat disagreeable odour, but is perfectly free from aldehydes and ketones.

The great difficulty in working this process is to avoid side reactions. Above $300^{\circ}$ and in the presence of certain catalysts (e.g. iron), carbon monoxide changes rapidly to the dioxide with deposition of carbon. The monoxide is also reduced to methane by hydrogen in the presence of nickel or iron. Conditions must be carefully adjusted to avoid these side reactions. Patart describes his process in some detail in the February issue of the Bulletin de la Societé d'Encouragement pour l'Industrie Nationale, and discusses the prospects of its commercial adoption.

More recent work, using metallic suboxides as catalysts, has been carried out by Audibert. Higher oxides of nickel and of copper are reduced by the reaction mixture of carbon monoxide and hydrogen in situ, and Audibert found that with these catalysts temperature is the controlling factor. Between $225^{\circ} \mathrm{C}$. and some limit between $275^{\circ}$ and $300^{\circ} \mathrm{C}$., depending on the nature of the catalyst, methyl alcohol is the sole reduction product of carbon monoxide.

Patents were taken out in Germany in 1922 for a process very similar to Patart's, and a plant was erected at Merseburg in 1923 capable of turning out about twenty tons of alcohol per day. This synthetic alcohol is now being exported by Germany in considerable quantities.

$$
\text { NO. } 2895 \text {, VOL. I I } 5 \text { ] }
$$

